Article

\title{
The Absence of Presence and the Presence of Absence: Social Distancing, Sacraments, and the Virtual Religious Community during the COVID-19 Pandemic
}

\author{
Helen Parish \\ Department of History, The University of Reading, Reading RG6 6AH, UK; h.l.parish@reading.ac.uk
}

Received: 30 April 2020; Accepted: 30 May 2020; Published: 3 June 2020

check for updates

\begin{abstract}
The response of churches to the challenges presented by the global COVID-19 pandemic invites a closer examination of the relationships between virtual and embodied religious communities during a time of social distancing. The speed and the scale of the closure of church buildings during Easter 2020 sheds light upon the multiplicity of practical, emotional, and spiritual responses to a relationship between church and people that is increasingly dominated by online interactions. Such a seismic shift in social culture opens up the possibility and challenges of a new understanding of belonging and participation in a religious community. Given its liturgical, pastoral, and sacramental significance, Easter 2020 was a highly charged moment for the relationship between the Christian churches and the faithful, and between religious worship and social media. In the shift from embodied community to virtual congregation that followed, the material absence of physical presence in collective worship was striking, as was the psychological presence of that absence. This paper analyses different understandings of religion, church, and community in the period of a pandemic, and argues for the value of an approach that situates the debates spawned in the context of historical precedent, personal experience, and theoretical approaches to networks, communities, religion, and social media.
\end{abstract}

Keywords: religious community; social networks; COVID-19; sacraments; online religion

\section{Introduction}

On Saturday 14 March 2020, the Prefecture of the Pontifical Household announced that "because of the current global public health emergency, all the Liturgical Celebrations of Holy Week will take place without the physical presence of the faithful." (Vatican 2020). The decision was announced as the COVID-19 pandemic spread across Italy and Europe. By March 2020, the global death toll from the coronavirus was rising rapidly, with many countries implementing draconian measures to slow the spread of the disease. Churches in Rome had been temporarily closed earlier in March but then re-opened to allow the faithful to pray and to participate in Eucharistic adoration. However, across Italy and the wider world, the cessation of public worship, including the celebration of the sacraments, was enforced as a means of reducing the spread of infection. In the United Kingdom, the Archbishops of Canterbury and York first suspended public worship, with the Eucharist celebrated in churches behind closed doors, but then responded to the actions of the government, writing to clergy to with the instruction that church buildings must be closed "not only for public worship, but for private prayer as well and this includes the priest or lay person offering prayer in church on their own". If they wished, clergy would be permitted to abstain from the celebration of the sacrament of Holy Communion "for such time as this is not physically accessible to lay people". A celebration of the Eucharist could take place only within the walls of the priest's home, in a form that enabled the faithful to participate 
in a spiritual communion. In the celebration of Holy Communion, including those that were shared online with the faithful, it was to be made clear "that this is in intention an expression of the shared life of the Body of Christ, not the offering of an individual."(Church of England 2020).

The impact of these decisions was monumental and without precedent in the modern world. The closure of churches and the prohibition of the celebration of the sacraments in the presence of a congregation created a stark divide between the individual and their Christian community. Given the liturgical, pastoral, and sacramental significance of Holy Week and Easter in the life of the church, this was a highly charged moment for the relationship between the Christian churches and the faithful, and between religious worship and social media. In the shift from embodied community to virtual congregation that followed, the material absence of physical presence in collective worship was striking, as was the psychological presence of that absence. The physical and the collective is a central component of the narratives of Easter; the gathering of the disciples with Jesus in the upper room for the last supper, the physical washing of feet as an act of service and humility, the human suffering of Christ on the cross and those who watched him die, and the risen Christ walking with the disciples on the road to Emmaus. It was the coming together of members of the Christian community to celebrate the Eucharist that defined the structure and the character of early Christianity (Davies 1997). The nature of the Christian church and its liturgical practices have clearly evolved over the centuries. However, the online streaming of the Mass, Holy Communion, and other forms of Christian worship into the homes of the faithful raises questions about the meaning of community in the context of what appears to be a rapidly changing model of the Christian church. The responses of churches to the spread of COVID-19 invite reflection upon the fluidity of the opportunities that are presented for sacramental celebration, and for the participation of the virtual congregation within it, and the extent to which these might modify assumptions about the virtual and embodied presence of religion within society.

\section{The Expansion of the Virtual Church Community}

Setting aside these more substantial questions for a moment, it is clear that the streaming of the liturgical celebrations through digital and social media very rapidly created its own audience. The Holy Week and Easter events that were broadcast and shared by Vatican media online reached an audience of millions around the world, extending far beyond the Catholic faithful (Glatz 2020). Nearly 5.5 million users registered more than 14.5 million views on the Vatican News website, which livestreamed the Holy Week liturgies with live commentary in six languages and with sign-language interpretation. Close to 18 million viewers watched the live video feeds of Holy Week events on the Vatican News Facebook page. During Holy Week, the @Pontifex Twitter account reached 50 million followers, and the @Franciscus Instagram accounts exceeded 7 million followers. Vatican News tweets received 61 million views and received 31,000 mentions. The Pope's Easter Sunday Mass was watched by more than 8.1 million households, close to 50 percent of the television audience in Italy (Glatz 2020; Lubov 2020). Online access to major papal Masses, liturgies, and services is not new, but Easter 2020 was the first occasion on which all major Holy Week and Easter events were broadcast worldwide.

A similar pattern of engagement with liturgical celebrations streamed on social media can be observed elsewhere. The number of people attending Mass in the Welsh diocese of Wrexham more than tripled after its liturgies moved online. Close to 1300 people viewed the Palm Sunday Mass at St Mary's Cathedral, indicating the presence of a virtual congregation that was three times the size of the group that would normally attend the Palm Sunday celebration in the cathedral itself. Over the Easter Triduum, double the usual number of virtual worshippers attended the Mass of the Lord's Supper at the Cathedral, and the bishop's Good Friday meditation attracted an online audience of 379 , almost twenty times the size of the normal congregation. These spikes in online participation were not unique to the major feasts of the Triduum; attendance at weekday Masses has increased from 20 people to over three hundred, and close to three hundred people participated online in the office of Compline streamed from within the bishop's private chapel (Dodd 2020). The Archbishop of Canterbury, Justin Welby, streamed an online Easter Sunday service from his own kitchen, which 
attracted an online congregation on a scale that would not have been possible within the walls of the cathedral (Welby 2020). When the Roman Catholic church in the United States of America ceased the public celebration of Mass, many dioceses promoted participation in Masses that were broadcast on television. However, by the second weekend of the lockdown, a discernible shift was made towards the online streaming of liturgies to virtual congregations. Mary DeTurris Poust, director of communications for the Diocese of Albany, New York, observed that the virtual congregations at Mass streamed online might vary in size, but "if you put it all together you realize we are still connected, still one body". That same sense of the existence of a Christian community, joined together virtually, is evident in the words of the Bishop of Albany tweeted on 9 April that "Although we cannot celebrate together in local churches this evening, we are united by the great gift of the Eucharist that we commemorate at the Mass of the Last Supper. Our voices joined in prayer from our individual homes and via livestream will be a balm for a weary world." (Bishop of Albany 2020). On 17 April, the homily delivered by Pope Francis in the Santa Marta Mass reflected on these same themes: "the disciples had progressed in familiarity with the Lord. May the Lord also teach us this familiarity with Him, which is personal, but always communitarian: a familiarity in everyday life, in the sacraments, in the midst of the people of God" (Pontifex 2020).

The discussion and recognition of the burgeoning virtual congregations for online religion, and the vocabulary that attends them, resonate with a lexicon of community, familiarity, joining together, connected, one body, and the people of God. This is much more than an upsurge in spontaneous religiosity brought about by fear and isolation. Rather, it is something that creates (and is created by) a shifting understanding of the relationship between a religious community that is locally defined as a communion of believers, and in which relationships are already established, and the experience of an online virtual community that humanises in a time of isolation but also relies on bonds that may not be embodied in the physical world. The intersection of church, communication, and community has not been defined by theology and doctrine alone but also by the engagement of religion with social networks and with the evolution of new technologies that shape both communication and the message itself. As COVID-19 became a global pandemic in 2020, nowhere was this symbiotic relationship between church and technology more evident than in the sudden and rapid proliferation of digital, online, religious worship. Churches of all denominations were swift to exploit the capacity of social media, websites, and online communities to act as a conduit for religious belief, liturgy, and pastoral support during periods of social distancing in which the doors of places of public worship were closed.

\section{Church, Community, and Communication in the Past}

Of course, this is far from the first time that social and information-sharing networks have sat at the heart of the transformation of the traditional structures of organised religion. Christianity has been reinventing itself and redefining its relationship with its faithful for two millennia. This particular use of social media in 2020 may be novel, but the assumptions that underpin it are firmly anchored in the past. Robert Darnton's persuasive analysis of social networks in pre-revolutionary France encourages us to reflect upon the ways in which "the marvels of communication technology in the present have produced a false consciousness about the past-even a sense that communication has no history, or had nothing of importance to consider before the days of television and the internet". Communication may appear the most important activity of modern life, but the 21st century world is far from being the only human society concerned with information and its transmission (Darnton 2012). The evangelical reformers of the sixteenth century declared the invention of printing with movable type to be an act of God, opening the presses to preach, establishing a pattern of communication that was new in its form and its content. Their message spread not only in the printed word, but through the transmission of that word through social networks, in a way that was impossible to suppress. Luther's friend Friedrich Myconius claimed that it had taken barely two weeks for Luther's 95 Theses to spread throughout the empire, and two more for their content to be familiar across Christian Europe. Even acknowledging Myconius' less than objective stance, the power of the printing press was widely recognised by Luther's 
opponents, and the capacity for evangelical ideas to spread, like a contagion, through the networks of the corpus Christianorum, well understood.

The emergence of print as a form of mass media proliferated access to information, encouraging a permanence of such information and a standardisation of its presentation. As a result, the printing press was instrumental in the emergence of a different sense of community and society, and the creation of the kind of "imagined communities" described by Benedict Anderson (Anderson 1991; Eisenstein 1993). The translation of belief from one medium to another, whether into the printed word or into the vernacular, reshaped not just the human social networks through which it was transmitted but also the relationship between the human and the divine. God became an accessible entity that could be approached without the mediation of priest and church, and the faith communities created by traditional cosmologies were replaced by the imagined communities of nation (Eisenstein 1993). Walter Ong's work posits a plausible connection between the shift from oral to literate culture and the similar reconfiguration of the structures of human knowledge and thought that followed (Ong 1982). That same potential for social communication and imagined communities to effect a transformation of religious experience is evident in the responses of the church and faithful to the challenges presented by the spread of COVID-19. The mechanism is different; digital media, not the material printed word, lie at the heart of the rapid expansion of the intersections between religious belief and new modes of communication. However, the issues remain the same. To what extent are (religious) relationships that are constructed and articulated in these new forms of communication, including social media, "real"?

\section{Religion Online and Online Religion}

The definition of fixed categories of community as something that is rooted in a particular physical space comes under pressure from the identification of community as networks that are static in neither space nor time. However, how do online networks or communities of this type function, and at what point does it make sense to talk of an online group as more than just a group but as a community? As Gustavo Mesch has observed, the necessity for physical presence in order to satisfy social needs is difficult to quantify (Mesch and Ilan 2006). Mesch's multivariate analysis exposes the extent to which, at least among the young, "without controlling for the intensity, content, and activities of the relationship, online friends tend to be perceived as less close than face-to-face friends". Indeed an online "distance" in connections and relationships is not the same as a geographical distance. Close personal relationships range widely and are not usually restricted to particular interests or conversations but rather grow out of shared experiences and a sense of mutual trust. Online relationships, however, tend to be less well integrated into everyday life, which exacerbates the sense of distance. Without integrating the embodied identity of the participants into the structure of social interactions and virtual networks that they create, the networks within online communities may struggle to avoid a tendency to isolate (Kayahara 2006). As Graham Ward reminds us, the hero, Christian, in John Bunyan's The Pilgrim's Progress, enquires of the two fellow travellers who have joined him "Where have you come from?", inviting a recognition that the "faith communities of the future will increasingly concern themselves with defining what it is to belong." (Ward 2006; Foley 2002). Participating and belonging are not one and the same. The relationship between society and technology is surely one of co-construction, shaped by culture, language, conventions, and mentalities (Mayr 1986; Gitelman 1999; Allen 2020; Feenberg 1999; Misa et al. 2003).

To what extent might digital technology both communicate information about religion and facilitate a participation and belonging, filling the void left by the suppression of physical, communal religion? Despite its online presence, the centrality of the embodied community remains essential to many forms of modern Christianity, and physical participation in the actions of the religious community still provides, as much as it did in the past, structure for time and space. In the virtual religious community, "church" (and here, we can perhaps borrow the language of Reformation evangelicalism) ceases to imply physical edifice and comes to mean the community of the faithful, not tied to place, but structured and supported by the new structures of social interaction that take place 
online. The internet is not simply a repository of information but a social space in which "networked religion" is able to function (Campbell 2005a, 2005b). Here, the distinction made by Christopher Helland between online religion and religion online is particularly apposite. This typology, first articulated in 1999, posits the existence of a clear demarcation between religious websites that provide users with unrestricted freedom and interactivity (online religion) and what were then the majority of religious web sites, which provide information but without opportunities for interaction (religion online). The latter conceives the internet as a tool for communication but not one that can meaningfully be understood as a social space or network. Helland's heuristic model may still hold weight, but the pace of change in the recent relationship between churches and the internet certainly blurs the boundaries between religion online and online religion, and between online and offline belief and action (Kruger 2005; Helland 2005). Teresa Berger's study of liturgical practice in a digital world certainly encourages us to take a nuanced approach to the question of whether online religion is of necessity disembodied; communities at prayer, she points out, have always been characterized by "richly complex notions of liturgical communion across time and space." (Berger 2018). As Falcone has argued, just virtual worlds, including religious worlds, are not imaginary spaces, so entering into them "does not require a leap of faith, it only requires the relevant technology." (Falcone 2019). However, interactions between technology, society, and culture are fluid and complex, and the relationship between the physical and virtual worlds of religion and belief is no exception. Neither the origins nor the influence of these interactions is uni-directional; in the emergence of participatory online religious activity during the first weeks of the COVID-19 pandemic, it is already possible to observe mutual influence, opposition, and acceptance, as well as a degree of uncertainty and questioning of the potential and the limitation inherent in these kinds of religious interactions.

\section{Virtual Presence or Embodied Community?}

These questions are not new, and the dialogue between churches and digital technologies clearly predates the demands and the concerns raised by the COVID-19 pandemic. The first line of the statement issued by Pontifical Council for Social Communications on The Church and the Internet (2002) declared the "Church's interest in the Internet (to be) a particular expression of her longstanding interest in the media of social communication, seeing the media as an outcome of the historical scientific process by which humankind "advances further and further in the discovery of the resources and values contained in the whole of creation."'". The history of communication is a central part of the history of the journey of humanity, and the Church recognises the positive capacities of the Internet to carry religious information and teaching beyond physical barriers and frontiers. The Pontifical Council recognised the potential for social media to complement religious practice and to provide a means by which the Church can communicate with particular groups but was also clear in its assertion that "the virtual reality of cyberspace cannot substitute for real interpersonal community, the incarnational reality of the sacraments and the liturgy, or the immediate and direct proclamation of the gospel." (Foley 2002). Participation in online worship is not, in the eyes of the Pontifical Council, an acceptable alternative to participation in a physical interpersonal community and in the reality of the liturgical celebration of Mass. The pastoral constitution Gaudium et Spes (1965) was clear in its assertion that although digital technologies might present opportunities for alternative modes of interaction, such interactions were artificial and potentially destructive of the bonds of human social relationships. "When he consciously takes part in the life of social groups, (man) carries out the design of God manifested at the beginning of time, that he should subdue the earth, perfect creation and develop himself". The exploitation of technology in such a way as to alienate human beings from one another presents a challenge to the will of God, and to the "deepest of bonds" that link mankind to its history. Whatever the importance of technology in the modern world, its potential use-deliberately or inadvertently - to erode necessary human experience of social and interpersonal relationships opened the door to a dangerous form of tyranny and coercive domination (Pope 1965a). Religion, if it becomes simply a global repository of information, is deprived of that sense of membership and belonging 
that has long been perceived as central to the dynamic and human experience of the faith community. Forty years later, the language and guiding principles of Gaudium et Spes were still evident in the 2002 statement on The Church and the Internet.

However, the use of virtual communities and social media during the 2020 pandemic to bridge the gap between the demands of social distancing and the longstanding prioritisation of propinquity in Christian worship has reinvigorated this dialogue and redefined its parameters. This is particularly evident in the debate over the validity of "virtual" sacraments, particularly the Eucharistic consecration, synchronous and asynchronous participation in liturgy and worship, the interaction between local pastoral responses to lay concerns, and a universal theology viewed through the lens of a global virtual community (Jacobs 2007; Campbell 2013). The transfer of the sacraments into the digital or virtual realm carries with it the potential to disembody the essence of Christianity so that it becomes a cacophony of information and observation and ceases to be a religion that is lived out within the human, physical community. Such anxieties underpin Graham Ward's complaint that the network of communications opened up by virtual religion runs the risk of creating a community of believers without any anchor in the physical embodiment of faith in the life of the Christian community Ward (2006). Online, membership of the Christian community becomes based upon access to a computer rather than access to the sacrament of baptism, with the sacerdotal and sacramental function of the priesthood giving way to the proliferation of unlicensed and unsupervised Christian ministry. The erosion of the embodied community identity coincides with the collapse of individual identity, removing mankind from the narrative of salvation history and turning God into a creation of an online humanity that remodels religion in a space provided by virtual reality. Any rapid emergence of online communities of belief, such as that which took place in the early months of 2020, has the potential to provoke a seismic shift, emerging from the dissonance in collective worship between the absence of physical presence and the material presence of absence, and enacted in the relationship between human and divine, church and people, and sacrament and community. The response of churches and believers to the loss of physical social space during the COVID-19 pandemic raises more questions than it answers about the relationship between religion and social media, and the nature of the networks, communities, and sacramental ministry that it creates.

The online availability of liturgical celebrations has the potential to create a virtual Christian church and community that extends across the globe. However, a universal Christian church with a mission and sacramental ministry that reaches, virtually, into the homes of its community cannot entirely mirror some of the structures and parameters of organised religion. The shift to online engagement with religion in response to COVID-19 was rapid and in many ways effective. However, although church leaders have embraced the value and potential of this new connection between religion and social media, that embrace has not been imbued with a sense that this is a permanent relationship. In the decades following Vatican II, the Roman Catholic Church has maintained that it is a necessary duty for the faithful to attend Mass on Sundays and other days of obligation, by being physically present in the church. The ability to watch Mass on screen, or listen to a radio broadcast, does not in usual circumstances constitute the fulfilment of that obligation. The Catechism (2182) attaches value to participation in the communal celebration of the Sunday Eucharist as a "testimony of belonging" in which the faithful "strengthen one another under the guidance of the Holy Spirit". The absence of a priest or "other grave cause" does permit absence from such communal celebration, and this is reflected in the dispensation from the obligation to attend Mass for as long as is required during the COVID-19 pandemic. However, that dispensation does not require that the faithful watch Mass on television or online, suggesting that the community of the church at prayer is not coterminous with the online virtual community and its liturgies (Davies 1997; Catholic 1994). Watching a streamed Mass might enable Catholics to feel connected with their parish and with the Church, when they cannot gather together, and the practice of spiritual communion provides an opportunity to seek the sustaining grace of God and maintain a connection to the wider Christian community (Bazin and Cottin 2004; Irwin 2005). 
More problematic, perhaps, is the loss of the sense of connection that comes from membership of an embodied worshipping community. Physical presence in a church is easier to recognise in oneself and in others than virtual presence in an online congregation, in which the use of avatars, an inability to see or hear the presence of others, and the lost sense of touch can diminish that sense of fellowship. At the sharing of the peace, members of a physical congregation shake hands with each other-family, friends, and strangers. That physical contact reflects the connections that already exist but also forms new bonds, bringing all participants into a tangible community under Christ. The connectivity between the real and the virtual world is easier to sustain in contexts in which the Christian community takes largely the same form in both and where those reciprocal bonds of recognition and community are already formed. The anonymity of online worship may be attractive to some but can impede the development of the kind of trust in social media-based religious communities that more normally comes from real-world relationships. In some cases, the transfer of parish congregations into the virtual world of post-COVID-19 religion will undoubtedly mean that membership of the Christian community remains comparable and consistent. However, the sheer scale of engagement with religion on social media and in digital forms during the COVID-19 lockdowns suggests that the proliferation of online content is doing more than simply enabling those real-world communities that are already well formed to meet on the other side of the virtual divide.

\section{Easter 2020: A Case Study}

Easter celebrations in April 2020 provide an instructive example of the ways in which the relationships between churches and social media have been negotiated as a result of the pandemic, and the relationships between church and people stretched to accommodate the forced changes to the nature of the religious community. Federico Lombardi SJ., in a series of articles on the theme of Living through the Crisis, contrasted the traditional gathering of crowds of 200,000 or more in St Peter's Square with the communication of the Easter message by Pope Francis, alone, speaking to the "square assembled by the media, where compassion, expectation and hope intersect". Every aspect of physical participation has been surrendered to the efforts to reduce the spread of COVID-19, but in Lombardi's eyes, this is a natural moment for the watching world to seek consolation and comfort and "compensate with communication through media". Historically, the Urbi et Orbi blessing points to the universal nature of the church, and the connections between the crowd gathered in Rome and the assembly of the listening faithful across the globe. The "Mystical Body" of Christ, in Lombardi's words, is a "spiritual reality which manifests itself when the assembly is physically united and present, but which is not bound and limited to physical presence, and paradoxically, in these days, can be experienced in a stronger and more explicit way." (Lombardi 2020). In Toronto, the Roman Catholic Archbishop Cardinal Thomas Collins has long been a proponent of the online and television broadcast of religious services. Standing before the altar in an empty St. Michael's Cathedral Basilica on Good Friday, the Cardinal observed that "This is normally a time that we have many people together". However, by observing the requirements of social distancing, and the prohibition of large gatherings, the Christian now fulfils the commandment to "love thy neighbour" by maintaining a physical distance, in which individuals protect their neighbours by staying at home. Humans are, he suggests, meant to be social creatures, to live in a community. The fact that this is no longer possible might well help to inculcate a greater appreciation of the kinds of social interaction that were taken for granted before the global pandemic. However, whatever the limitations on physical access to churches, "the Mass does not stop. We pray for the people every single day, and people join in, in a certain way, through livestream." (Toronto 2020). The phrase "in a certain way" touches on some of the more problematic areas of uncertainty around online or virtual religious communities. For the Anglican Bishop of Toronto, Andrew Absil, there is something unsettling about the celebration of Easter liturgies in front of a camera rather than a full, visible congregation. "Knowing that you are not gathering as a community" is the most difficult aspect of the virtual celebration of Easter, an observation that suggests a discernible difference between the meaning and feeling of community in the virtual and embodied context. For all the benefits afforded 
by the recent interactions between religion and social media, the relationship between pastor and congregation does not always make a full and meaningful transition from one form of community to the other. The desire of Christian churches to celebrate Easter in as full and celebratory a form as possible online cannot compensate entirely for the absence of the physical and the spectacular that feature in traditional celebrations-creeping to the cross, the stripping of the altars, the washing of feet, and paschal fires-that provide a sensory rather than virtual experience. The intersection of past and present in the celebration of Passover is strikingly evident, given that this marks the beginning of the exodus from Egypt by those Jews who remained indoors as plague swept over the land. To celebrate alone, and separated from the community, is to invert the message that inheres in traditional celebrations. One rabbi sought to compensate for this lack of physical community by asking for copies of family pictures from his congregation that he could attach to chairs in order to make them more physically present before his eyes. In Italy, a priest filled the pews of his empty church with photographs of his parishioners. Father Giuseppe Corbari, pastor of the Saints Quirico and Giulitta parish in Robbiano, explained that "the need arose to at least see the faces of the people in my parish, because celebrating Mass looking at the empty pews was sad" but noted that the same was true in reverse; "this gesture meant a lot to the people, who even in staying home, were still present ... People also want to be present as a community, as a parish, even if they are each at home." (Allen 2020). Photographs of parishioners are not coterminous with their physical presence, but for the priest, and for his congregation, pictures helped to compensate for the required social distance between the members of the community. Prayer also helped to provide and strengthen bonds within the invisible community of the church; "Even without the physical presence of the faithful", Fr Corbari reported, "I am in communion with the Church. When I pray, I pray feeling the presence of the parishioners, so I pray with them and for them. I am trying to create closeness to them ..." .

Such comments invite further consideration of the extent to which radio, television, or internet celebrations of Mass are able to fill the gap left by the prohibition of the public celebration of the sacraments in the real or physical world. Watching Mass on television, or joining an online congregation, is a different type of religious experience both for the participant and for the priest. The experience of religious worship on social media may still have the capacity to inspire and to communicate but is less able to create a sense of communal lived experience in the life of the church, an experience for which the embodied congregation is necessary. Any assertion that a defining part of what it means to be human is the intrinsic capacity to engage in sign-making and to be physically present further diminishes the sense that the virtual experience of liturgy is the same as that in the real world (Williams 2015; Lyons 2009). The ability to share physical presence, gestures, and words is an essential part of the fullness of experience in a religious-and human-community, and its absence further encourages an individualisation of religious experience and belief.

\section{A “Virtual” Eucharist?}

The most dramatic arena for conflict between the virtual and the embodied religious experience is in the sacrament of the Eucharist. While it is possible to observe, and to some extent participate, in the celebration of Mass as an online virtual congregant, the physical participation in the Eucharist by receiving the elements is not feasible outside the embodied setting. As Cardinal Thomas Collins observes, while the liturgy of the Word can be transmitted online with relative ease, the "incarnate encounter with Christ" in the celebration of the Eucharist cannot take place online (Albert 2005; Cheong et al. 2012; Labenek 2014). Contact with and consumption of the consecrated bread and wine, or indeed any sacrament, requires the presence of the human body. Just as the baptism of someone who is not physically present is impossible, so participation in the sacrifice of the Mass requires a physical presence. In the words of Fr Thomas Weinandy (Vatican International Theological Commission), "the sacrament is the action of Christ performed by the minister, and for that action to take place, the priest and the penitent must be in communion with one another, in a physical manner". On this basis, the physical presence of both consecrated bread and wine and the community of the faithful 
is an absolute necessity for the validity of the enactment of the sacrament (Flynn and Condon 2020). That same assumption that the Christian community is physically present is embedded in the language used by the laity in the liturgy of the Mass, which is consciously in the first person plural: "Lift up your hearts. We lift them to the Lord", "May the Lord accept the sacrifice at your hands, for our sake and the sake of all his church".

The Code of Canon Law (Catholic Church 1983) articulates that same status of the Eucharistic sacrifice as a communal celebration: except for a just and reasonable cause, a priest is not to celebrate the Eucharistic sacrifice without the participation of at least some member of the faithful (Canon 906). The prohibition of the celebration of Mass without the presence of a server, or a member of the faithful who could respond as a representative of the membership of the Church, dates back to the 12th century. However the prohibition is not entirely rigid, and exceptions to the demands of the canon include "time of pestilence" and the necessity of bringing viaticum to the dying. However, the positioning of the Mass as the central pillar of the mission and vocation of the priest is evident in the language used in Presbyterorum Ordinis (c.13) of the Second Vatican Council in which the "daily celebration of Mass is strongly urged, since even if there cannot be present a number of the faithful, it is still an act of Christ and of the Church. Thus when priests join in the act of Christ the Priest, they offer themselves entirely to God, and when they are nourished with the body of Christ they profoundly share in the love of him who gives himself as food to the faithful ... In the recitation of the Divine Office, they offer the voice of the Church which perseveres in prayer in the name of the whole human race, together with Christ who 'lives on still to make intercession on our behalf.'" (Pope 1965b). The 2013 Directory for the Ministry and the Life of Priests repeats this sentiment in its articulation of the "irreplaceable value for the priest of the daily celebration of the Holy Mass-the 'source and summit' of the priestly life - even if it should not be possible to have the faithful present. In this regard Benedict XVI teaches: "To this end I join the Synod Fathers in recommending "the daily celebration of the Holy Mass, even when the faithful are not present." (Congregation for the Clergy 1994). The official use of the 1662 Book of Common Prayer in the Church of England still sets out an explicit requirement for the presence of at least three people for Communion. A statement issued from the Diocese of London on 31 March 2020 in response to the particular challenges presented by the closure of churches noted that "The Eucharist is intended, normatively, to be a corporate, not a private act, because it is given to offer the people spiritual nourishment ... to build up the body of Christ in love and fellowship ... and to strengthen and confirm our faith in him." (London College of Bishops 2020). With this in mind, local parishes were permitted to suspend the celebration of Holy Communion "until they are able to meet in person again". Alternatively, "To ensure congregational involvement, where a parish church wishes to continue to celebrate the eucharist ... and only the priest can be present, it should, whenever possible, be livestreamed, so that others can at least (as Cranmer put it) "see with our eyes" even if they cannot "smell with our noses, touch with our hands and taste with our mouths." This enables the kind of spiritual reception that is at the heart of the sacrament, even if physical partaking is not possible." However, the London College of Bishops also encouraged the faithful to pray that this time of separation would be short, and that "God will give us a hunger and a thirst for that time when once again we can gather together to lift up our hearts in praise and adoration, to be nourished by the bodily reception of this sacrament..."

Predictably, such statements invite a questioning of whether, if priests celebrate the Eucharist with congregants watching online, those watching might derive benefits from observing the consecration of the elements. Such a model is not far removed from the practice of ocular communion which was, for centuries, the most common experience of the Eucharistic celebration in Roman Catholic Europe. The words of institution, the sound of the sanctus bell, and the elevation of the host emphasised the importance of the precise moment at which the bread and wine become the body and blood of Christ. Lay reception of the consecrated elements was infrequent and prescribed at the Fourth Lateran Council (1215) as an obligation to be fulfilled once per year, in the Easter season. During the plague epidemics in Milan in the 1570s, Carlo Borromeo instructed that altars be built in every quarter of the city in 
order to enable the faithful to observe the celebration of Mass from their windows. The ritual of the penitential plague procession, and large congregations of participants, compounded the possibility of contagion and contravened medical and civic rules for isolation. Borromeo's solution was to move the activity into private homes during periods of quarantine, imposing a new model of devotional and ritual activity that attempted to reconcile religious zeal with the safety of the civic community. His Constitutiones et decreta de cura pestilentiae included a chapter devoted to spiritual activities in public spaces and closed-up homes, with the clergy instructed to teach the laity a variety of prayers, litanies, and Psalms before quarantine. During the quarantine, households were summoned to prayer by the ringing of bells across the parish, with litanies or supplications chanted with one group singing from the windows or the doors of their homes, and another group singing in response. Interactive rituals of this type enabled participants to "project themselves back onto the streets and re-join each other virtually" during a time of confinement at home (Chiu 2018). The resonances with the Christian world of 2020 are striking.

Ocular communion prioritises the observed moment of consecration over the physical consumption of the elements, which has some benefits in the time of COVID-19, but translating this model from the physical context of the church building to the virtual world of the live-streamed liturgy is still not entirely straightforward. A faith that is incarnate and lived in the world is not the same as a faith that is lived virtually. If members of the virtual congregation have bread and wine in front of them at home, could the priest consecrate that bread and wine remotely? Such a solution to sacramental separation has certainly been proposed. In a statement presented by the Episcopal Chaplaincy at Harvard, Aidan Luke Stoddart proposed a "Eucharist via Zoom", at which congregants prepare bread and wine in their own location. The Eucharistic consecration "will extend not only to the elements in her proximity, but to the bread and wine of all those who have gathered digitally to participate in the Eucharistic liturgy ... We will be present to one another and to God, even though physically we will be apart". Sufficient spiritual presence at the Eucharist, he argued, would be located in the aspect of the heart and soul as much as in the more common physical contexts for the celebration of the Eucharist (Stoddart 2020). If the unity of the faithful in the celebration of the Eucharist extends beyond the local into the entire church, past and present, what part does intention play in the validity and efficacy of the sacrament for celebrant and for congregation? (Delap 2020; Vallely 2020). Even the sharing of an online communion and consecration via Zoom, Facebook, or other social media does not enable the church and its members to participate in the sharing of one bread and one cup. Giles Fraser, priest-in-charge at St Mary's, Newington, likened the online Eucharistic celebration to the viewing of the popular television programme Masterchef. "Why are food programmes so popular when no one at home gets to taste or even smell the food?" Fraser asks, "and is this what church is to become, a kind of simulacrum of itself, a digital re-presentation of live-giving bread that is apparently offered, but cannot be eaten?" (Fraser 2020). That tension between the tangible and the intangible, the embodied and the virtual, still sits at the heart of the challenge for churches seeking to engage worshipping communities in online liturgies.

In response, proposals to address the enforced period of fasting from the Eucharist for the duration of the pandemic have included the consecration of wafers that could be delivered to parishioners' homes, as an alternative to the "Communion-in-place" model advanced by Stoddart, or the synchronous virtual gathering of the community for an agape meal in which the food is blessed (not consecrated) and then shared. Some of these proposals, including "drive-thru" Holy Communion or the postal delivery of consecrated hosts, have raised concerns that are practical, theological, and pastoral (Meyers 2020). However, common to all of these concerns is the meaning and value of "virtual Communion", whether ocular reception, in-place consecration, or the consumption of consecrated elements within private houses. The other area of common ground lies in the implicit sense that discussions of virtual consecration and communion in the world of COVID-19 are firmly anchored in the practices of a past in which the physical sharing of Communion was once experienced, and in the anticipation of a future in which such practices are once again restored. The live-streaming of church services, the sharing of 
spiritual or ocular communion, and concerns about the validity of the consecration of the elements by a priest who stands alone all suggest a desire to repeat, or recapture, a more "normal" model rather than push the burgeoning relationship between church, religion, and social media to a position of pre-eminence that undermines the necessity of embodied participation in the life of the church.

\section{Conclusions}

The definition of religious community in the Christian church sits at the intersection of theological, sociological, and pastoral constructions of the meaning and purpose of belonging. Whether as an embodied community or a virtual community, religion and church invoke a language of gathering and fellowship that projects the imagery of the kingdom of God into the hearts and minds of the faithful and facilitates the expression of a lived faith. Religions are some of the oldest organisational forms, yet the breadth and depth of the impact of COVID-19 on their communities has required radical change in the face of an escalating crisis. Within days, even hours, of the announcement that public worship in churches would cease, the live-streaming of services, opportunities for synchronous and asynchronous worship, and new virtual communities became part of religious and community life. Homes have been transformed into recording studios; live-streaming has facilitated lay participation, not just observation; and local churches have become the focal point for a global virtual religious community. The shifting nature of the relationship between religions and digital media presents a solution to the problems of the present but is a solution that is also anchored in the past; throughout its history, the Christian church has relied upon social networks and the intersections of real and imagined communities, to provide a location for incarnate faith. However, while the eyes and ears soak up the observed and audible presence of the online virtual worshipping community, the other senses encounter only the absence of the tangible, tastable, and olfactible. The challenge that faces religion in its complex relationship with social media is precisely this: the absence of physical presence in collective worship, juxtaposed with the psychological presence of that absence. However, this is not to downplay the importance of the debates. If it is religion, and the religious community, that provides humanity with its narrative structure, then the interaction of faith and community with social media, social distancing, and sacramental theology during the COVID-19 pandemic will surely be an important part of that history.

Funding: The APC was funded by the University of Reading.

Conflicts of Interest: The author declares no conflict of interest.

\section{References}

Albert, Jean-Pierre. 2005. Who Believes in Transubstantiation? L'Homme 175-76: 369-73.

Allen, Elise Ann. 2020. As coronavirus empties churches, Italian priest fills pews with photos of parishioners. Crux. Available online: https://cruxnow.com/church-in-europe/2020/03/as-coronavirus-empties-churchesitalian-priest-fills-pews-with-photos-of-parishioners/ (accessed on 10 April 2020).

Anderson, Benedict. 1991. Imagined Communities. Reflections on the Origins and Spread of Nationalism. London: Verso. Bazin, Jean-Nicolas, and Jerome Cottin. 2004. Virtual Christianity: Potential and Challenge for the Churches. Geneva: WCC Publications.

Berger, Teresa. 2018. @ Worship: Liturgical Practices in Digital Worlds. New York: Routledge.

Bishop of Albany. 2020. Twitter. Available online: https://twitter.com/AlbBishopEd/status/1248328659129249794 (accessed on 20 April 2020).

Campbell, Heidi. 2005a. Exploring Religious Community Online. We Are One in the Network. New York: Peter Lange.

Campbell, Heidi. 2005b. Spiritualising the internet. Uncovering discourses and narratives of religious internet usage. Online. Heidelberg Journal of Religions on the Internet 1: 1-26.

Campbell, Heidi. 2013. Digital Religion: Understanding Religious Practice in New Media Worlds. Abingdon: Routledge. Catholic, Church. 1994. Catechism of the Catholic Church. Liguori: Liguori Publications.

Cheong, Pauline Hope, Peter Fischer-Nielsen, Stefan Gelfgren, and Charles Ess. 2012. Digital Religion, Social Media and Culture: Perspectives, Practices and Futures. New York: Peter Lang. 
Chiu, Remi. 2018. Singing on the Street and in the Home in Times of Pestilence: Lessons from the 1576-78 Plague of Milan. In Domestic Devotions in Early Modern Italy. Edited by Maya Corry, Marco Faini and Alessia Meneghin. Leiden: Brill, pp. 27-44.

Church of England. 2020. Coronavirus Covid-19 Guidance for Parishes in Holy Week. Available online: https://www.churchofengland.org/more/media-centre/coronavirus-covid-19-guidance-parishes/holyweek-and-easter-2020 (accessed on 20 April 2020).

Congregation for the Clergy. 1994. Directory on the Ministry and Life of Priests. Available online: https://www.vatican. va/roman_curia/congregations/cclergy/documents/rc_con_cclergy_doc_31011994_directory_en.html (accessed on 20 April 2020).

Darnton, Robert. 2012. Poetry and the Police Communication Networks in Eighteenth-Century Paris. Cambridge: Belknap Press.

Davies, Michael. 1997. A Short History of the Roman Mass. Kansas City: TAN Books \& Publishers.

Delap, Dana. 2020. How we shared the bread and wine on Zoom. The Church Times. Available online: https://www.churchtimes.co.uk/articles/2020/17-april/comment/opinion/how-we-shared-the-breadand-wine-on-zoom (accessed on 20 April 2020).

Dodd, Liz. 2020. Mass attendance triples in Wales thanks to online services. The Tablet. Available online: https: //www.thetablet.co.uk/news/12778/mass-attendance-triples-in-wales-thanks-to-online-services (accessed on 19 April 2020).

Eisenstein, Elizabeth. 1993. The Printing Revolution in Early Modern Europe. Cambridge: Cambridge University Press.

Falcone, Jessica M. 2019. Sacred realms in virtual worlds: The making of Buddhist spaces in Second Life. Critical Research on Religion 7: 147-67. [CrossRef]

Feenberg, Andrew. 1999. Questioning Technology. London: Routledge.

Flynn, J. D., and E. D. Condon. 2020. Confession by Phone, Skype, or Emoji? Could it Happen during Coronavirus Pandemic? Available online: https://angelusnews.com/faith/confession-by-phone-skype-or-emoji-could-ithappen-during-coronavirus-pandemic/ (accessed on 10 April 2020).

Foley, John P. 2002. Pontifical Council for Social Communications: The Church and Internet. Vatican City: Libreria Editrice Vaticana. Available online: http://www.vatican.va/roman_curia/pontifical_councils/pccs/documents/ rc_pc_pccs_doc_20020228_church-internet_en.html (accessed on 18 April 2020).

Fraser, Giles. 2020. Zoom eucharist felt like an episode of Masterchef-and I loved it. The Post. Available online: https://unherd.com/thepost/zoom-eucharist-felt-like-an-episode-of-masterchef-and-i-loved-it/ (accessed on 18 April 2020).

Gitelman, Lisa. 1999. Scripts, Grooves and Writing Machines. Representing Technology in the Edison Era. Stanford: Stanford University Press.

Glatz, Carol. 2020. Vatican reveals huge online growth over Easter. The Tablet. Available online: https://www.thetablet. co.uk/news/12779/vatican-reveals-huge-online-growth-over-easter (accessed on 18 April 2020).

Helland, Christopher. 2005. Online Religion as Lived Religion. Methodological Issues in the Study of Religious Participation on the Internet. Online. Heidelberg Journal of Religions on the Internet 1: 1-16.

Irwin, Kevin W. 2005. Models of the Eucharist. New York: Paulist Press.

Jacobs, Stephen. 2007. Virtually Sacred: The Performance of Asynchronous Cyber-Rituals in Online Spaces. Journal of Computer-Mediated Communication 12: 1103-21. [CrossRef]

Kayahara, Jennifer. 2006. Community and Communication: A Rounded Perspective. In Networked Neighborhoods: The Connected Community in Context. Edited by Patrick Purcell. London: Springer.

Kruger, Oliver. 2005. Methods and Theory for Studying Religion on the Internet: Introduction to the Special Issue on Theory and Methodology. Heidelberg Journal of Religions on the Internet 1: 1-7. [CrossRef]

Labenek, Andrew W. 2014. The Promise and Problematic of the Virtual Eucharist Mass according to the Roman Catholic Church's Position in "The Church and the Internet.". Electronic Thesis and Dissertation Repository, Western University, London, ON, USA.

Lombardi, Federico. 2020. Empty Piazzas, Filled Spaces. Vatican News. Available online: https://www.vaticannews.va/ en/vatican-city/news/2020-04/empty-piazzas-filled-spaces-lombardi-living-through-the-crisis-1.html (accessed on 20 April 2020).

London College of Bishops. 2020. The Eucharist in a Time of Physical Distancing. Diocese of London Communications. Available online: https://www.london.anglican.org/articles/the-eucharist-in-a-time-of-physical-distancing/ (accessed on 19 April 2020). 
Lubov, Deborah Castellano. 2020. Alessandro Gisotti on Massive Growth in Vatican Media Engagement This Easter \& Holy Week. Zenit. Available online: https://zenit.org/articles/alessandro-gisotti-reflects-on-massivevatican-growth-this-easter-holy-week/ (accessed on 21 April 2020).

Lyons, Nathan. 2009. Signs in the Dust. A Theory of Natural Culture and Cultural Nature. Oxford: OUP.

Mayr, Otto. 1986. Authority, Liberty, and Automatic Machinery, in Early Modern Europe. Baltimore: Johns Hopkins Press.

Mesch, Gustavo, and Talmud Ilan. 2006. The Quality of Online and Offline Relationships: The Role of Multiplexity and Duration of Social Relationships. The Information Society 22: 137-48. [CrossRef]

Meyers, Ruth A. 2020. Spiritual Communion in a Season of Social Distancing. Available online: https: //cdsp.edu/2020/04/spiritual-communion-in-a-season-of-social-distancing/ (accessed on 10 April 2020).

Misa, Thomas J., Brey Philip, and Feenberg Andrew. 2003. Modernity and Technology. Cambridge: MIT Press.

Ong, Walter. 1982. Orality and Literacy: The Technologizing of the Word. London: Methuen.

Pontifex. 2020. Twitter. Available online: https:/twitter.com/Pontifex/status/1251092023987355650 (accessed on 20 April 2020).

Pope, Paul, VI. 1965a. Gaudium et Spes. Available online: http://www.vatican.va/archive/hist_councils/ii_vatican_ council/documents/vat-ii_const_19651207_gaudium-et-spes_en.html (accessed on 20 April 2020).

Pope, Paul, VI. 1965b. Decree on the Ministry and Life of Priests. Available online: http://www.vatican.va/archive/hist_ councils/ii_vatican_council/documents/vat-ii_decree_19651207_presbyterorum-ordinis_en.html (accessed on 20 April 2020).

Roman Catholic Church. 1983. New Code of Canon Law. Available online: http://www.vatican.va/archive/codiuris-canonici/eng/documents/cic_introduction_en.html (accessed on 20 April 2020).

Stoddart, Aidan Luke. 2020. A Eucharistic Proposal for a Time of Pandemic. Available online: https:/www.harvardepiscopalians. org/a-eucharistic-proposal?fbclid=IwAR157aV-8O-8fcnjBvKcMvWSWLrWe5UNmnEiiHLjfttkefvCccRHPkcoGbw (accessed on 20 April 2020).

Toronto, Sun. 2020. Reaching the Masses. Available online: https://www.youtube.com/watch?v=R4xhWqoqNBo (accessed on 20 April 2020).

Vallely, Paul. 2020. This is teaching us about the mass. The Church Times. Available online: https://www.churchtimes. co.uk/articles/2020/9-april/comment/columnists/paul-vallely-this-is-teaching-us-about-the-mass (accessed on 19 April 2020).

Vatican, News. 2020. Covid-19. Vatican Holy Week Celebrations under Study. Available online: https://www. vaticannews.va/en/vatican-city/news/2020-03/vatican-coronavirus-easter-triduum-celebrations.html (accessed on 19 April 2020).

Ward, Graham. 2006. The Future of Religion. Journal of the American Academy of Religion 74: 179-86. [CrossRef]

Welby, Justin. 2020. Twitter. Available online: https://twitter.com/JustinWelby/status/1249220707466305536 (accessed on 20 April 2020).

Williams, Rowan. 2015. Response to Kerr, Hedley, Pickstock, Ward and Soskice. Modern Theology 31: 630-36. [CrossRef]

(C) 2020 by the author. Licensee MDPI, Basel, Switzerland. This article is an open access article distributed under the terms and conditions of the Creative Commons Attribution (CC BY) license (http://creativecommons.org/licenses/by/4.0/). 